\title{
Physiological changes in the cattle Egret, Bubulcus ibis, as a Bioindicator of air pollution in New Damietta City, Egypt
}

\author{
Naglaa F. Elarabany ${ }^{1 *}$ and Omnya A. El-Batrawy ${ }^{2}$ \\ ${ }^{1}$ Zoology Department, Faculty of Science, Damietta University, Egypt \\ ${ }^{2}$ Environmental Sciences Department, Faculty of Science, Damietta University, Egypt \\ *elarabany@du.edu.eg
}

\begin{abstract}
Different heavy metals accumulate in the environment due to intensive human activities, which adversely affect wildlife. Biota usually develops different biological responses to face such stress; analysis of these biological responses could be used as a biomarker of pollutants. The current study aimed to compare hematologic and biochemical parameters in cattle egret collected from industrial and rural sites in New Damietta City, Egypt, to assess the effect of heavy metal pollution. Selected heavy metals concentrations including copper $(\mathrm{Cu})$, cadmium $(\mathrm{Cd})$, zinc $(\mathrm{Zn})$, lead $(\mathrm{Pb})$, nickel $(\mathrm{Ni})$, arsenic $(\mathrm{As})$, and mercury $(\mathrm{Hg})$ were measured for the two sampling sites in aerosols from ambient air, feathers, and blood samples. Some hematological, biochemical parameters and oxidative stress markers were measured in the blood using a non-invasive method. Sampling was done in summer and winter during 2015-2016. Heavy metal concentrations in aerosols from the industrial area were significantly higher than those from the rural site. The highest concentrations of all heavy metals in both sites were recorded in summer. Cattle egret from the industrial area showed a significantly decreased RBCs count and PCV level and increased WBCs count, total protein, albumin, triglycerides, uric acid, ammonia, creatinine, bilirubin, and cortisol levels. Moreover, birds from the industrial area suffered from environmental stress as indicated by elevations of MDA, GPx and catalase activity in industrial birds as compared to rural birds. In conclusion, birds from the industrial areas were adversely affected by the elevated concentrations of selected heavy metals, so it could be used as an effective bioindicator of environmental contamination.
\end{abstract}

Key words: Air Quality, resident birds, heavy metals, biomarkers, oxidative stress, Cattle Egret.

\section{INTRODUCTION}

The ambient air quality has deteriorated to such an extent that it adversely affects the health and welfare of human beings (Das et al., 2015). Air pollution in the last decades is continuously uprising and become a global problem due to different intensive anthropogenic activities including industrial discharges, vehicle emissions and other activities critically affected the atmospheric environment (Swaileh and Sansur, 2006). The exposure to different air pollutants affects all the environmental systems including human health and wildlife inhabiting such contaminated habitat (Albayrak and Mor, 2011).

Bioindicators are organisms or a species or a group of species, whose function and/or population status can be used to monitor the environmental quality. Changes in the population status, behaviour and physiology of such organisms are used to predict the occurrence of any environmental problem within a given ecosystem. Resident wild birds have been proved to be useful bioindicators of heavy metals levels in the environment because they are widely distributed, spend their entire lives in the same area, have a wide feeding spectrum, 
Naglaa F. Elarabany and Omnya A. El-Batrawy

and are sensitive to different environmental toxins (Kekkonen et al., 2012). Birds as a bioindicator can provide a good picture of the possible risks to human more than measuring the physical parameters of the environment itself (Adout et al., 2007). Sonne et al. (2010) used the significant decline in raptor populations as an indicator of DDT toxicity.

Cattle egret, Bubulcus ibis, is a resident wild bird which could be used as a reliable ecological indicator of atmospheric pollutants because it is resident, widely distributed in different habitats and closely associated to human activities (Thongcharoen et al., 2018).

Most airborne heavy metals are biologically reactive elements which interfere with different metabolic and biochemical processes in a living organism (Koivula et al., 2011). They cause toxic effects by altering the activity of different enzymes, increasing free radicals and disrupting the antioxidant mechanism (Isaksson, 2010).

Many studies have been conducted to evaluate the accumulation of heavy metals in biological samples such as eggs, feathers, brain, kidney and liver (Brait and Antoniosi Filho, 2011; Kaur and Dhanju, 2013; Aloupi et al., 2017). Measuring the accumulation of the heavy metals and their concentration is a not enough tool to estimate the potential risks for the wildlife status but it is important to assess the effect of such pollutants on different physiological functions rather than their concentrations. The current study was conducted in New Damietta region and aimed (1) to use the changes in physiological parameters of cattle egret to assess heavy metal pollution in two different area, industrial area and rural area and (2) to compare the selected heavy metals between the two areas and in biological samples (feather and blood) during summer and winter seasons of 2015-2016.

\section{MATERIALS AND METHODS} Study Area

This study was conducted in New Damietta City, Damietta Governorate, Egypt ( $31^{\circ} 41^{\prime} 42^{\prime \prime} \mathrm{N}$ and $31^{\circ} 27^{\prime} 52^{\prime \prime} \mathrm{E}$ ), which is 30 years old and located along the Mediterranean Sea at $4.5 \mathrm{Km}$ from Damietta port. It is also surrounded by wide vegetation areas including palm trees and small villages. The City contains different activities including residential areas (housing), industrial sector, petroleum activities, and reconstruction areas. In the last few decades, this region has an exponential population growth along with extensive anthropogenic pressure due to industrial activities, electricity plants, fertilizer industries, pesticides, chemicals, steel and plastic factories and intensive petroleum activities which may cause severe environmental pollution and affect the biota inhabiting it. Two areas were selected for sampling, industrial area (IA) and rural area (RA).

\section{Sampling of Aerosols in Ambient Air}

Sampling of aerosols was carried out during two seasons (summer and winter) from 2015 to 2016. Sampling was carried out for $8 \mathrm{hrs}$ with a mean flow rate of $1.5 \mathrm{l} / \mathrm{min}$. The sampling equipment was located on a building at about $5 \mathrm{~m}$ from the ground. Particles were collected on Whatman $47 \mathrm{~mm}$ membrane filters with $0.45 \mu \mathrm{m}$ pores size. Filters were weighed in temperature and relative humidity control.

\section{Blood and Feather Sampling}

During two seasons (summer and winter) from 2015 to 2016, blood samples and feathers were collected from 23 cattle egrets caught with trap cages in 2 sites of New Damietta city, representing industrial area (IA) and rural area (RA).Licenses for capture and blood sampling of birds were obtained from the Egyptian Environmental Affairs Agency (EEAA). All procedures were approved by the local Ethical 


\section{Physiological changes in the cattle Egret, Bubulcus ibis, as a Bioindicator of air pollution in New Damietta City, Egypt}

Committee and the State Office for Environment Protection.

Birds were caught, weighed, and blood samples were collected from the brachial vein, representing no more than $1 \%$ of the body weight (Lumeij, 1997) using a $3 \mathrm{ml}$ syringe. Sampling was done with less than three minutes, between capture and blood sampling, to minimize handling stress.

Each blood sample was divided into three aliquots, the $1^{\text {st }}$ aliquot was used for heavy metal analysis, the $2^{\text {nd }}$ aliquot was used for haematological measurements and the $3^{\text {rd }}$ aliquot was left for $1 \mathrm{~h}$ and then centrifuged for $20 \mathrm{~min}$; the isolated plasma samples were collected and stored at $-20{ }^{\circ} \mathrm{C}$ until assayed for biochemical parameters later in the same day.

Accumulation of heavy metals in feathers occurs during its development which differs across the plumage (Johnston and Janiga, 1995), so feathers from different body parts may have different concentration of the heavy metals (Dauwe et al., 2003). To standardize the procedures, only the two innermost secondary feathers were collected, packed in metal-free polyethylene bags and stored in $-20{ }^{\circ} \mathrm{C}$ until further analysis. After sampling, birds were released.

\section{Heavy Metals Analysis}

Heavy metal concentrations in aerosols samples were determined. A definite section of the filter on which suspended particles were accumulated was cut and digested in $3 \mathrm{M}$ nitric acid. Concentrations of some metals were measured following well-established techniques (Lodge and James, 1988).

Blood and feathers were used as biomarkers to show the immediate and long-term exposure, respectively. Collected feathers were washed with $0.25 \mathrm{M} \mathrm{NaOH}$ (Scheifler et al., 2006), followed by rinsing 3 times in distilled water, in order to remove any attached exogenous heavy metals. The washed feathers were allowed to dry for $24 \mathrm{~h}$ at $80^{\circ} \mathrm{C}$ in the oven to a constant dry mass, crunched to powder and weighed to the nearest $0.1 \mathrm{mg}$ using a digital balance (Dauwe et al., 2000). For digestion, $0.5 \mathrm{~g}$ from each feather sample was digested in 3:1 nitric acid $\left(70 \% \mathrm{HNO}_{3}\right)$ and hydrogen peroxide $\left(\mathrm{H}_{2} \mathrm{O}_{2}\right)$, alternately, in a drying oven at $60{ }^{\circ} \mathrm{C}$ for $48 \mathrm{~h}$ (Adout et al., 2007). The whole blood samples were digested using wet protocol described by Cid et al.(2018). Finally, $5 \mathrm{~mL}$ of deionized water was added to all samples. All samples were measured for $\mathrm{Cu}, \mathrm{Cd}, \mathrm{Zn}$, $\mathrm{Pb}, \mathrm{Ni}, \mathrm{As}$ and $\mathrm{Hg}$ and determined using atomic absorption spectrophotometer, (analyst100 Spectrometer, Perkin Elmer, USA).

\section{Haematological and Biochemical Analysis}

Haematological parameters including blood cells count (RBCs), packed cell volume (PCV), haemoglobin content $(\mathrm{Hb})$, and white blood cells (WBCs) were measured within one hour of sampling using automated blood cell counter.

Plasma samples were analysed for biochemical parameters such as glucose (GLU), alanine aminotransferase (ALT), aspartate aminotransferase (AST), total protein (TP), albumin, urea, uric acid, total bilirubin (TB), creatinine, total lipids (TL), cholesterol, triglycerides and cortisol. Moreover oxidative stress markers including, catalase (CAT), malondialdehyde (MDA) and glutathione peroxidase (GPx) were also measured in plasma, while superoxide dismutase (SOD) activity was measured in RBCs lysate. All parameters were determined using available commercial kits, absorbance values of all samples and standards were measured by a UV spectrophotometer. 
Naglaa F. Elarabany and Omnya A. El-Batrawy

\section{Statistical Analysis}

The current study results were presented as means \pm SE. all parameters were tested for normal distribution. Data were statistically analysed using one-way analysis of variance (ANOVA). Level of significance was considered at $P<0.05$. All statistical analyses were performed using XLSTAT program.

\section{RESULTS}

Metal Concentrations in Ambient Air

Table (1) shows the atmospheric heavy metal concentrations in both industrial and rural areas measured in summer and winter seasons during 20152016. The current study results show that in both study sites, element concentrations during summer were significantly higher than their respective concentrations in winter $(\boldsymbol{P}<$ 0.01). Moreover, metal concentrations in the industrial area in both seasons were significantly higher than those in the rural area $(\boldsymbol{P}<0.03)$. Zinc showed the highest concentration in both areas during the two seasons.
During summer the order of metal concentrations in IA area was ordered as follow: $\mathrm{Zn}>\mathrm{Cu}>\mathrm{Pb}>\mathrm{Hg}>\mathrm{Ni}>\mathrm{Cd}>\mathrm{As}$ with average concentration $329 \pm 32.9$, $229 \pm 23.1,179 \pm 48.43,59.3 \pm 4.4,42 \pm 8.6$ and $16.9 \pm 1.4 \mathrm{ng} / \mathrm{m}^{3}$; respectively. The metal order in the RA was slightly different from their order in IA area, it was $\mathrm{Zn}>\mathrm{Cu}>\mathrm{Pb}>\mathrm{Hg}>\mathrm{As}>\mathrm{Ni}>\mathrm{Cd}$ with average concentration $247 \pm 35.1,112 \pm$ $24.2,68 \pm 37.4,5.3 \pm 1.45,4.6 \pm 0.73,3.8 \pm$ 1.2 and $0.87 \pm 0.5 \mathrm{ng} / \mathrm{m}^{3}$; respectively.

Regarding winter samples, the metal order in the aerosols from IA was $\mathrm{Zn}>\mathrm{Pb}>\mathrm{Cu}>\mathrm{Ni}>\mathrm{Hg}>\mathrm{As}>\mathrm{Cd}$ with average concentration $294 \pm 26.4,132 \pm$ $27.3,91 \pm 13.84,36 \pm 2.5,12.5 \pm 5.6,9.1 \pm$ 1.6 and $7.7 \pm 0.59 \mathrm{ng} / \mathrm{m}^{3}$; respectively. The metal order in the aerosols from RA was slightly different from their order in IA where $\mathrm{Zn}>\mathrm{Cu}>\mathrm{Pb}>\mathrm{Ni}>\mathrm{Hg}>\mathrm{As}>\mathrm{Cd}$ with average concentration $231 \pm 37.4,69 \pm$ $14.5,47 \pm 25.3,3.1 \pm 0.95,2.6 \pm 0.42,1.4 \pm$ 0.3 and $0.56 \pm 0.06 \mathrm{ng} / \mathrm{m}^{3}$, respectively.

Table (1): Seasonal atmospheric heavy metals concentrations $\left(\mathrm{ng} / \mathrm{m}^{3}\right)$ in the industrial area (IA) and rural area (RA) during summer and winter 2015-2016.

\begin{tabular}{|c|c|c|c|c|}
\hline \multirow{2}{*}{$\begin{array}{c}\text { Heavy } \\
\text { metal }\end{array}$} & \multicolumn{3}{|c|}{ IA } & \multicolumn{2}{|c|}{ RA } \\
\cline { 2 - 5 } & Summer & Winter & Summer & Winter \\
\cline { 2 - 5 } $\mathrm{Cu}$ & $229 \pm 23.1^{*}$ & $91 \pm 13.84^{*}$ & $112 \pm 24.2$ & $69 \pm 14.5$ \\
$\mathrm{Cd}$ & $16.9 \pm 1.4^{*}$ & $7.7 \pm 0.59^{*}$ & $0.87 \pm 0.5$ & $0.56 \pm 0.06$ \\
$\mathrm{Zn}$ & $329 \pm 32.9^{*}$ & $294 \pm 26.4^{*}$ & $247 \pm 35.1$ & $231 \pm 37.4$ \\
$\mathrm{~Pb}$ & $179 \pm 48.43^{*}$ & $132 \pm 27.3^{*}$ & $68 \pm 37.4$ & $47 \pm 25.3$ \\
$\mathrm{Ni}$ & $42 \pm 8.6^{*}$ & $36 \pm 2.5^{*}$ & $3.8 \pm 1.2$ & $3.1 \pm 0.95$ \\
$\mathrm{As}$ & $13.4 \pm 4.03^{*}$ & $9.1 \pm 1.6^{*}$ & $4.6 \pm 0.73$ & $1.4 \pm 0.3$ \\
$\mathrm{Hg}$ & $59.3 \pm 4.4^{*}$ & $12.5 \pm 5.6^{*}$ & $5.3 \pm 1.45$ & $2.6 \pm 0.42$ \\
\hline
\end{tabular}

* Significantly different in the same season in both sampling localities. Data represented in means \pm SE.

\section{Metals Concentrations in Feathers}

Table (2) shows element concentrations in feathers of cattle egret from the industrial and rural area. All measured elements in feathers showed significantly higher concentrations in industrial birds during summer than their concentration in rural birds during the same season $(P \leq 0.05)$. Levels of studied elements in feathers of cattle egret during summer in IA are arranged in the following order: $\mathrm{Zn}>\mathrm{Pb}>\mathrm{Cu}>\mathrm{Ni}>\mathrm{As}>$ $\mathrm{Hg}>\mathrm{Cd}$ with mean concentrations 206.3 \pm $9.77,8.87 \pm 1.98,7.19 \pm 1.68,2.46 \pm 0.39$, $0.89 \pm 0.16,0.89 \pm 0.15$ and $0.30 \pm 0.02$ ppm, respectively. Heavy metals order in 


\section{Physiological changes in the cattle Egret, Bubulcus ibis, as a Bioindicator of air pollution in New Damietta City, Egypt}

$\mathrm{RA}$ was $\mathrm{Zn}>\mathrm{Cu}>\mathrm{Pb}>\mathrm{Ni}>\mathrm{Hg}>\mathrm{As}>\mathrm{Cd}$ where their mean concentrations were $114.3 \pm 13.75,5.63 \pm 0.92,2.35 \pm 0.89$, $1.87 \pm 0.13,0.55 \pm 0.34,0.42 \pm 0.21,0.21 \pm$ $0.01 \mathrm{ppm}$, respectively.

Regarding winter samples, no significant changes were found between industrial and rural birds for all elements except $\mathrm{Zn}, \mathrm{Ni}$ and $\mathrm{Hg}$ which were significantly higher in industrial birds during winter than rural birds $(\boldsymbol{P}=0.002$,
0.02 and 0.04; respectively).The element order in the feather from IA was slightly different from their order during summer where $\mathrm{Zn}>\mathrm{Cu}>\mathrm{Pb}>\mathrm{Ni}>\mathrm{Hg}>\mathrm{As}>\mathrm{Cd}$ with average concentration 148.85 \pm 7.3, $5.36 \pm 0.51,2.53 \pm 0.92,1.9 \pm 0.48,0.51 \pm$ $0.2,0.29 \pm 0.13$ and $0.15 \pm 0.06 \mathrm{ppm}$, respectively. Rural birds in winter had the same element order in the feather as that of summer samples.

Table (2): Seasonal heavy metal concentrations (ppm) in feathers samples of cattle egret, Bubulcus ibis, from industrial area (IA, $\mathrm{n}=11)$ and rural area (RA, $\mathrm{n}=12)$ during summer and winter 2015-2016. (n) Represents sample size.

\begin{tabular}{|c|c|c|c|c|}
\hline \multirow{2}{*}{$\begin{array}{c}\text { Heavy } \\
\text { metals }\end{array}$} & \multicolumn{3}{|c|}{ Areas } \\
\cline { 2 - 5 } & \multicolumn{3}{|c|}{ IA } & RA \\
\hline & Summer (n=6) & Winter (n=5) & Summer (n=7) & Winter (n=5) \\
\hline $\mathrm{Cu}$ & $7.19 \pm 1.68^{*}$ & $5.36 \pm 0.51$ & $5.63 \pm 0.92$ & $4.68 \pm 0.69$ \\
$\mathrm{Cd}$ & $0.30 \pm 0.02^{*}$ & $0.15 \pm 0.06$ & $0.21 \pm 0.01$ & $0.13 \pm 0.03$ \\
$\mathrm{Zn}$ & $206.3 \pm 9.77^{*}$ & $148.85 \pm 7.3^{*}$ & $114.3 \pm 13.75$ & $99.14 \pm 8.27$ \\
$\mathrm{~Pb}$ & $8.87 \pm 1.98^{*}$ & $2.53 \pm 0.92$ & $2.35 \pm 0.89$ & $1.21 \pm 0.53$ \\
$\mathrm{Ni}$ & $2.46 \pm 0.39^{*}$ & $1.9 \pm 0.48^{*}$ & $1.87 \pm 0.13$ & $0.68 \pm 0.02$ \\
$\mathrm{As}$ & $0.89 \pm 0.16^{*}$ & $0.29 \pm 0.13$ & $0.42 \pm 0.21$ & $0.14 \pm 0.01$ \\
$\mathrm{Hg}$ & $0.89 \pm 0.15^{*}$ & $0.51 \pm 0.2^{*}$ & $0.55 \pm 0.34$ & $0.32 \pm 0.08$ \\
\hline
\end{tabular}

* Significantly different in the same season in both sampling localities. Data represented in means \pm SE.

\section{Metals Concentrations in Blood}

Table (3) shows metal concentrations in blood samples of cattle egret collected from the industrial and rural area. All analysed elements were detected in the cattle egret blood samples. Blood $\mathrm{Cu}$ concentration in cattle egret (mean \pm SE) was $1.5 \pm 0.4$ and $0.89 \pm 1.4$ ppm during summer and winter, respectively in industrial birds, those levels were significantly higher than those in rural birds $(\boldsymbol{P}<0.01)$. Similarly, blood $\mathrm{Pb}$ concentration in industrial birds was $1.01 \pm 0.02$ and $0.87 \pm 0.59 \mathrm{ppm}$ during summer and winter, respectively which were significantly higher than those of rural birds $(\boldsymbol{P}<0.03)$.
Regarding the other elements, $\mathrm{Zn}$, $\mathrm{Ni}, \mathrm{As}, \mathrm{Hg}$ and $\mathrm{Cd}$, industrial birds contained a significantly higher concentration during summer in comparison to their respective concentration in rural birds $(\boldsymbol{P} \leq 0.05)$, but no significant changes were recorded between industrial birds and rural birds during winter. The concentrations of heavy metals in blood samples from IA during summer showed a different order from feathers: $\mathrm{Zn}>\mathrm{Ni}>\mathrm{Cu}>\mathrm{Pb}>\mathrm{Hg}>\mathrm{As}>\mathrm{Cd}$, the same order was found during winter but $\mathrm{Cd}$ preceded As. The blood concentrations from rural birds showed the following order: $\mathrm{Zn}>\mathrm{Ni}>\mathrm{Cu}>\mathrm{Pb}>\mathrm{As}>$ $\mathrm{Hg}>\mathrm{Cd}$ during summer and $\mathrm{Zn}>\mathrm{Ni}>\mathrm{Pb}>$ $\mathrm{Cu}>\mathrm{Hg}>\mathrm{Cd}>$ As during winter. 
Naglaa F. Elarabany and Omnya A. El-Batrawy

Table (3): Seasonal heavy metals concentrations ( $\mathrm{ppm}$ ) in blood samples of cattle egret, Bubulcus ibis, from industrial area $(\mathrm{IA}, \mathrm{n}=11)$ and rural area $(\mathrm{RA}, \mathrm{n}=12)$ during summer and winter 2015-2016. (n) Represents sample size.

\begin{tabular}{|l|c|c|c|c|}
\hline \multirow{2}{*}{ Blood heavy metal } & \multicolumn{4}{|c|}{ Areas } \\
\cline { 2 - 5 } & \multicolumn{2}{|c|}{ IA } & \multicolumn{2}{c|}{ RA } \\
\cline { 2 - 5 } & Summer (n=6) & Winter (n=5) & Summer (n=7) & Winter (n=5) \\
\hline Blood $\mathrm{Cu}(\mathrm{Cu}-\mathrm{B})$ & $1.5 \pm 0.4^{*}$ & $0.89 \pm 1.4^{*}$ & $0.7 \pm 0.3$ & $0.23 \pm 0.12$ \\
Blood $\mathrm{Cd}(\mathrm{Cd}-\mathrm{B})$ & $0.08 \pm 0.01^{*}$ & $0.03 \pm 0.01$ & $0.03 \pm 0.01$ & $0.03 \pm 0.001$ \\
Blood $\mathrm{Zn}(\mathrm{Zn}-\mathrm{B})$ & $14 \pm 2.41^{*}$ & $2.89 \pm 1.56$ & $2.58 \pm 0.72$ & $2.44 \pm 0.11$ \\
Blood $\mathrm{Pb}(\mathrm{Pb}-\mathrm{B})$ & $1.01 \pm 0.02^{*}$ & $0.87 \pm 0.59^{*}$ & $0.63 \pm 0.2$ & $0.53 \pm 0.12$ \\
Blood $\mathrm{Ni}(\mathrm{Ni}-\mathrm{B})$ & $2.71 \pm 0.53^{*}$ & $0.93 \pm 0.79$ & $1.84 \pm 0.70$ & $0.87 \pm 0.43$ \\
Blood As (As-B) & $0.51 \pm 0.01^{*}$ & $0.01 \pm 0.01$ & $0.23 \pm 0.01$ & $0.03 \pm 0.01$ \\
Blood $\mathrm{Hg}(\mathrm{Hg}-\mathrm{B})$ & $0.56 \pm 0.21^{*}$ & $0.25 \pm 0.1$ & $0.21 \pm 0.04$ & $0.19 \pm 0.05$ \\
\hline
\end{tabular}

* Significantly different in the same season in both sampling localities. Data represented in means \pm SE.

\section{Haematological Parameters}

Table (4) shows the results of red blood corpuscles count (RBCs), white blood cells count (WBCs), packed cell volume value (PCV) and haemoglobin content $(\mathrm{Hb})$ in the blood of cattle egret (Bubulcus ibis) caught in the industrial area (IA) and rural area (RA).

In the current study, the season within the same area did not affect haematological parameters, while habitat did. The count of RBCs and PCV value in blood were significantly lower in cattle egrets collected from the industrial area than those collected from the rural area in both seasons $(\boldsymbol{P}<0.001$, Table 4$)$. On the other hand, the number of WBCs in samples collected from the industrial site were significantly higher than those collected from the rural area in both seasons $(\boldsymbol{P}<0.01$, Table 4$)$.

Table (4): Haematological parameters of cattle egret, Bubulcus ibis, from industrial area (IA, $\mathrm{n}=11)$ and rural area $(\mathrm{RA}, \mathrm{n}=12)$ during summer and winter 2015-2017. (n) Represents sample size.

\begin{tabular}{|c|c|c|c|c|}
\hline \multirow{3}{*}{ Blood parameters } & \multicolumn{4}{|c|}{ Areas } \\
\hline & \multicolumn{2}{|l|}{ IA } & \multicolumn{2}{|c|}{ RA } \\
\hline & Summer $(n=6)$ & $\begin{array}{c}\text { Winter } \\
(\mathbf{n}=5)\end{array}$ & $\begin{array}{c}\text { Summer } \\
(n=7)\end{array}$ & $\begin{array}{c}\text { Winter } \\
(\mathbf{n}=5)\end{array}$ \\
\hline RBCs $\left(10^{6} / \mu 1\right)$ & $3.06 \pm 0.6^{*}$ & $3.9 \pm 0.41 *$ & $4.45 \pm 0.7$ & $4.7 \pm 0.32$ \\
\hline $\mathrm{Hb}(\mathrm{g} / \mathrm{dl})$ & $12.8 \pm 0.29$ & $11.9 \pm 0.49$ & $11.7 \pm 0.16$ & $10.9 \pm 0.51$ \\
\hline $\operatorname{PCV}(\%)$ & $31.52 \pm 5.40 *$ & $29 \pm 2.07 *$ & $55.12 \pm 4.35$ & $45.3 \pm 2.12$ \\
\hline WBCs $\left(10^{3} / \mu 1\right)$ & $5.45 \pm 0.95 *$ & $4.6 \pm 0.91 *$ & $3.35 \pm 1.45$ & $3.9 \pm 0.51$ \\
\hline
\end{tabular}

* Significantly different in the same season in both sampling localities. Data represented in means \pm SE.

\section{Plasma Enzymes and Metabolites:}

As shown in Table (5), all plasma biochemical indices were influenced by the habitat. Aspartate aminotransferase (AST) activity was significantly higher in industrial birds than in rural birds during summer $(\boldsymbol{P}=0.003)$ and winter $(\boldsymbol{P}=0.002)$. AST mean activity during summer was $55 \pm 1.92 \mathrm{U} / \mathrm{ml}$ and $25 \pm 3.29 \mathrm{U} / \mathrm{ml}$ in industrial and rural birds, respectively, while in was $46 \pm 3.41$ and $30 \pm 3.81 \mathrm{U} / \mathrm{ml}$ in IA and RA birds during winter; respectively.

Similarly, alanine aminotransferase (ALT) activity was significantly higher birds collected from the industrial area than those from the rural area during summer $(\boldsymbol{P}=0.009)$ and winter $(\boldsymbol{P}=0.003)$. 


\section{Physiological changes in the cattle Egret, Bubulcus ibis, as a Bioindicator of air pollution in New Damietta City, Egypt}

The summer activity of ALT in industrial birds was $47 \pm 2.84 \mathrm{U} / \mathrm{ml}$ and $23 \pm 3.21 \mathrm{U} / \mathrm{ml}$ in rural birds; similarly, it was $30 \pm 3.65$ $\mathrm{U} / \mathrm{ml}$ in cattle egret from the industrial area and $18 \pm 1.95 \mathrm{U} / \mathrm{ml}$ in cattle egret from the rural area during winter.

During summer, cattle egret from industrial area had higher mean plasma concentrations of protein $(11.39 \pm 0.62 \mathrm{~g} / \mathrm{l}$, $\boldsymbol{P}=0.002)$, albumin $(8.88 \pm 0.3 \mathrm{~g} / \mathrm{l}, \boldsymbol{P}=$ 0.004), ammonia $(242.47 \pm 42.25 \mu \mathrm{mol} / \mathrm{l}$, $\boldsymbol{P}=0.001)$, uric acid $(17.04 \pm 1.80 \mathrm{mg} / \mathrm{dl}$, $\boldsymbol{P}=0.031)$, bilirubin $(3.22 \pm 0.52, \boldsymbol{P}=0.05)$, creatinine $(0.54 \pm 0.06 \mathrm{mg} / \mathrm{dl}, \boldsymbol{P}=0.002)$, triglycerides $(445.16 \pm 53.91 \mathrm{mg} / \mathrm{dl}, \boldsymbol{P}=$ $0.02)$, and cortisol $(550 \pm 89.5 \mathrm{ng} / \mathrm{ml}, \boldsymbol{P}=$ $0.004)$ than the respective values in rural birds. However, cholesterol was significantly lower in industrial birds than in rural birds $(225.64 \pm 41.31 \mathrm{mg} / \mathrm{dl}, \boldsymbol{P}=$ 0.039).
The same significant differences were found during winter where industrial birds showed higher biochemical indices in comparison to rural birds. In industrial birds, the mean levels of total protein (10.62 $\pm 0.53 \mathrm{~g} / \mathrm{l}, \quad \boldsymbol{P}=0.0001)$, albumin (6.83 $\pm 0.18 \mathrm{~g} / \mathrm{l}, \quad \boldsymbol{P}=0.001)$, ammonia (212.90 $\pm 26.17 \mu \mathrm{mol} / \mathrm{l}, \boldsymbol{P}=0.001)$, uric acid (13.19 $\pm 1.52 \mathrm{mg} / \mathrm{dl}, \boldsymbol{P}=0.031$ ), bilirubin (3.15 $\pm 0.94 \mathrm{mg} / \mathrm{dl}, \boldsymbol{P}=0.05)$, creatinine $(0.44 \pm 0.08 \mathrm{mg} / \mathrm{dl}, \boldsymbol{P}=0.002)$, triglycerides $(421.51 \pm 55.16 \mathrm{mg} / \mathrm{dl}, \quad \boldsymbol{P}=0.02)$, and cortisol $(420 \pm 28.3 \mathrm{ng} / \mathrm{ml}, \boldsymbol{P}=0.004)$ had higher mean plasma concentrations than the respective rural birds while cholesterol was significantly lower in industrial birds than rural birds $(191.54 \pm 32.87 \mathrm{mg} / \mathrm{dl}, \boldsymbol{P}=$ 0.039). Finally, other parameters such as glucose and urea did not change significantly either between seasons nor habitat.

Table (5): Biochemical parameters of cattle egret, Bubulcus ibis, from industrial area (IA, n= 11) and rural area (RA, $n=12$ ) during summer and winter 2015-2016. (n) Represents sample size.

\begin{tabular}{|l|c|c|c|c|}
\hline \multirow{2}{*}{ Plasma parameters } & \multicolumn{4}{|c|}{ Areas } \\
\cline { 2 - 5 } & \multicolumn{2}{|c|}{ IA } & \multicolumn{2}{c|}{ RA } \\
\cline { 2 - 5 } & $\begin{array}{c}\text { Summer } \\
(\mathbf{n = 6})\end{array}$ & $\begin{array}{c}\text { Winter } \\
(\mathbf{n = 5})\end{array}$ & $\begin{array}{c}\text { Summer } \\
(\mathbf{n = 7})\end{array}$ & $\begin{array}{c}\text { Winter } \\
(\mathbf{n = 5})\end{array}$ \\
\hline AST $(\mathrm{U} / \mathrm{ml})$ & $55 \pm 1.92^{*}$ & $46 \pm 3.41^{*}$ & $25 \pm 3.29$ & $30 \pm 3.81$ \\
ALT $(\mathrm{U} / \mathrm{ml})$ & $47 \pm 2.84^{*}$ & $30 \pm 3.65^{*}$ & $23 \pm 3.21$ & $18 \pm 1.95$ \\
T. protein $(\mathrm{g} / \mathrm{dl})$ & $11.39 \pm 0.62^{*}$ & $10.62 \pm 0.53^{*}$ & $6.70 \pm 0.49$ & $5.48 \pm 0.73$ \\
Albumin $(\mathrm{g} / \mathrm{dl})$ & $8.88 \pm 0.3^{*}$ & $6.83 \pm 0.18^{*}$ & $2.53 \pm 0.1$ & $2.68 \pm 0.17$ \\
Ammonia $(\mu \mathrm{mol} / \mathrm{l})$ & $242.47 \pm 42.25^{*}$ & $212.90 \pm 26.17^{*}$ & $144.09 \pm 9.78$ & $106.99 \pm 35.13$ \\
Urea $(\mathrm{g} / \mathrm{dl})$ & $7.43 \pm 0.84$ & $8.22 \pm 0.67$ & $8.12 \pm 0.85$ & $8.96 \pm 1.02$ \\
Uric Acid $(\mathrm{mg} / \mathrm{dl})$ & $17.04 \pm 1.80^{*}$ & $13.19 \pm 1.52^{*}$ & $4.07 \pm 0.45$ & $3.85 \pm 1.24$ \\
Bilirubin $(\mathrm{mg} / \mathrm{dl})$ & $3.22 \pm 0.52^{*}$ & $3.15 \pm 0.94^{*}$ & $1.31 \pm 0.51$ & $1.23 \pm 0.43$ \\
Creatinine $(\mathrm{mg} / \mathrm{dl})$ & $0.54 \pm 0.06^{*}$ & $0.44 \pm 0.08^{*}$ & $0.15 \pm 0.03$ & $0.15 \pm 0.06$ \\
Cholesterol $(\mathrm{mg} / \mathrm{dl})$ & $225.64 \pm 41.31^{*}$ & $191.54 \pm 32.8^{*}$ & $474.36 \pm 13.88$ & $464.10 \pm 24.08$ \\
Triglycerides $(\mathrm{mg} / \mathrm{dl})$ & $445.16 \pm 53.91^{*}$ & $421.51 \pm 55.2^{*}$ & $212.9 \pm 17.38$ & $208.60 \pm 55.16$ \\
Cortisol $(\mathrm{ng} / \mathrm{ml})$ & $550 \pm 89.5^{*}$ & $420 \pm 28.3^{*}$ & $102 \pm 7.8$ & $98 \pm 6.8$ \\
Glucose $(\mathrm{mg} / \mathrm{dl})$ & $50.31 \pm 3.61$ & $46.88 \pm 4.47$ & $49.06 \pm 7.36$ & $50.69 \pm 11.34$ \\
\hline
\end{tabular}

* Significantly different in the same season in both sampling localities. Data represented in means \pm SE. 



\section{Oxidative Stress Biomarkers}

It was obvious from Table (6) that season did not affect the oxidative stress biomarkers in cattle egret, while sampling site seemed to be the principal source of change. In relation to the oxidative stress, lipid peroxidation product (malondialdehyde, MDA) was significantly higher in industrial birds in both summer and winter than the rural birds $(\boldsymbol{P}=0.004,0.02$, respectively $)$. Moreover, the antioxidant defence activity was also affected by the sampling site rather than the season, glutathione peroxidase activity increased significantly in industrial birds in both summer and winter as compared to rural birds $(\boldsymbol{P}=0.01$, 0.05 ; respectively). Similarly, catalase activity was significantly higher in industrial samples in both summer and winter than rural birds $(\boldsymbol{P}=0.0001,0.041$, respectively). Superoxide dismutase (SOD), on the other hand, did not show any significant changes.

Table (6): Oxidative stress biomarkers of cattle egret, Bubulcus ibis, from industrial area (IA, $\mathrm{n}=11$ ) and rural area (RA, $\mathrm{n}=12$ ) during summer and winter 2015-2017. (n) Represents sample size.

\begin{tabular}{|l|c|c|c|c|}
\hline \multirow{2}{*}{ Parameters } & \multicolumn{4}{|c|}{ Concentration } \\
\cline { 2 - 5 } & \multicolumn{2}{|c|}{ IA } & \multicolumn{2}{c|}{ RA } \\
\cline { 2 - 5 } & $\begin{array}{c}\text { Summer } \\
(\mathbf{n = 6})\end{array}$ & $\begin{array}{c}\text { Winter } \\
(\mathbf{n = 5})\end{array}$ & $\begin{array}{c}\text { Summer } \\
(\mathbf{n}=\mathbf{7})\end{array}$ & $\begin{array}{c}\text { Winter } \\
(\mathbf{n}=\mathbf{5})\end{array}$ \\
\hline MDA (nmol/ml) & $79.87 \pm 7.853^{*}$ & $59.8 \pm 9.06^{*}$ & $29.0 \pm 11.10$ & $18.0 \pm 7.02$ \\
GPx (U/ml) & $13.67 \pm 1.34^{*}$ & $12.53 \pm 1.166^{*}$ & $22.00 \pm 1.04$ & $18.5 \pm 0.95$ \\
CAT (U/l) & $529.3 \pm 38.11^{*}$ & $496.3 \pm 38.46^{*}$ & $135.6 \pm 34.40$ & $120.4 \pm 41.12$ \\
SOD (U/gm) & $165 \pm 32.8$ & $162 \pm 21.2$ & $157 \pm 19.3$ & $153 \pm 6.6$ \\
\hline
\end{tabular}

* Significantly different in the same season in both sampling localities. Data represented in means \pm SE.

\section{DISCUSSION}

Bio-indicators and the changes in their biomarkers could be used as an early warning of environmental contamination and to improve the processes of risk assessment for populations and their habitat (Martínez-Gómez et al., 2010). New Damietta region is considered one of the most important habitats for about 26 resident wild bird species and 40 migratory bird species (Abd-Allah et al., 2008). According to the available literature, the current work is the first study in Egypt using the resident wild birds (cattle egret) for bio-monitoring selected heavy metals in ambient air $(\mathrm{Cu}, \mathrm{Cd}, \mathrm{Zn}, \mathrm{Pb}, \mathrm{Ni}$, As, and $\mathrm{Hg})$.

\section{Metal Concentrations in Ambient Air}

Heavy metal concentrations in aerosols from the industrial area have significantly higher concentrations for all metals compared to those from the rural siteduring both seasons. The highest concentrations of all heavy metals in both sites were recorded in summer may be due to the extensive anthropogenic activities as transportation, industrial facilities and open waste burning which lead to increased emission of particulate matter (Salam et al., 2008). According to the heavy metal order, zinc had the highest concentration in both areas and both seasons followed by $\mathrm{Cu}$ and $\mathrm{Pb}$, while $\mathrm{As}$ and $\mathrm{Cd}$ had the lowest concentrations.

Zinc present in the air naturally but its concentrations are expected to elevate abnormally due to different anthropogenic activities such as construction work, traffic-related and residential activities (Awan et al., 2013). Copper can enter the environment through waste dumps, combustion of fossil fuels and wastes, 


\section{Physiological changes in the cattle Egret, Bubulcus ibis, as a Bioindicator of air pollution in New Damietta City, Egypt}

wood production and phosphate fertilizer production (ATSDR, 2004).

The concentration of $\mathrm{Pb}$ in aerosol samples were within the permissible limits $\left(1.0 \mu \mathrm{g} / \mathrm{m}^{3}\right)$ recommended by the Egyptian Environmental Affairs Agency (EEAA, 1995). $\mathrm{Pb}$ has been considered as a marker of vehicle traffic as constituents of leaded gasoline (Cheng et al., 2014). The lead-free fuel in vehicles may be responsible for the lower concentrations of $\mathrm{Pb}$ at all sites.

The mean concentration of $\mathrm{Ni}$ in IA was found higher than the permissible limit $\left(20 \mathrm{ng} / \mathrm{m}^{3}\right)$ of National Ambient Air Quality Standard (NAAQS, 2009) during both seasons. Both arsenic and cadmium are very toxic elements which present naturally in the environment with very low levels. The mean concentration of As in IA was found higher than the permissible limit $\left(6 \mathrm{ng} / \mathrm{m}^{3}\right)$ (NAAQS, 2009) during both seasons, while $\mathrm{Cd}$ levels were found below the permissible limit $\left(15 \mathrm{ng} / \mathrm{m}^{3}\right)$ (NAAQS, 1994) at all sites during both seasons except for IA in summer season.

As may be produced by copper producing industries or agricultural activities, while $\mathrm{Cd}$ mainly emitted from Industrial processes; burning of municipal wastes containing discarded $\mathrm{Ni}-\mathrm{Cd}$ batteries and plastics containing $\mathrm{Cd}$ pigments combustion sources and vehicular emissions including tire abrasions (Pal et al., 2014). Generally; heavy metal concentrations of IA of New Damietta City are lower than those reported for other industrial areas in Egypt (Zakey et al., 2008; El-Batrawy et al., 2017).

\section{Metal Concentrations in Biological Samples}

Feather is an indicator of long time exposure such as bioaccumulation of blood metals during their formation or mobilisation from internal organs (Leonzio et al., 2009), while blood reflects a limited or present time of exposure to heavy metals (Burger and Gochfeld, 2002).
Accumulation of heavy metals in the developing feather is considered to be an effective way of detoxification (Agusa $e t$ $a l ., 2005)$.The levels of heavy metals in the feathers and blood of adult cattle egrets have not been studied previously in Egypt, only one study reported their concentration in feathers of cattle egret chicks in Cairo (Burger et al., 1992). The concentration of different heavy metals in the bird's blood are highly regulated, any changes in their baseline concentration are indicators of changes in the bird's diet, habitat, mobilisation from internal tissue or even exposure to anthropogenic contaminants by inhalation (Rattner et al., 2008).

Heavy metal concentrations in feathers from industrial birds were greater than those in rural birds which indicate local sources for contamination such as the extensive marble industries, transportation activities, wood preservation, construction activities, petroleum refining activities and burning solid waste in New Damietta City.

Copper is very important for maintaining normal growth, metabolism and function (Pappas et al., 2006), Cu level in feather in the current study (ranged from 4.68 to $7.19 \mathrm{ppm}$ ) was higher than those reported for cattle egret in Pakistan (Malik and Zeb, 2009) and grey heron from Korea (Kim and Koo, 2007).

Cadmium is a toxic, non-essential heavy metal which does not accumulate in the food chain (Burger and Gochfeld, 2004). The average Cd level measured in egret feathers in the current study (ranged from 0.13 to $0.3 \mathrm{ppm}$ ) was higher than those recorded in common eider (Burger and Gochfeld, 2009) but lower than the threshold concentration of $2 \mu \mathrm{g} / \mathrm{g}$ which may adversely affect birds (Burger and Gochfeld, 2000).

Zinc is an essential heavy metal for feather development, normal body functions and reduces $\mathrm{Cd}$-induced renal toxicity. However, the concentration of $\mathrm{Zn}$ in the current study ( ranged from 99.14 to $206 \mathrm{ppm}$ ) is higher than those of black- 
crowned herons (Golden et al., 2003), tufted puffin (Burger and Gochfeld, 2009) and little egret (Zhang et al., 2006), but still lower than the dose which cause severe kidney damage, $200 \mathrm{mg} / \mathrm{g}$, (Hutton and Goodman, 1980).

Lead is a highly toxic, nondegradable heavy metal which cannot be regulated (Scheifler et al., 2006). The concentrations obtained in this study for $\mathrm{Pb}$ feathers were ranged from 1.21 to 8.81 ppm which were lower than those of Korean shorebirds (Kim and Koo, 2008) and great cormorants from Japan (Nam et $a l .$, 2005) but higher than those in Blackcrowned night heron (Kim and Koo, 2007).

Nickel is associated to feather pigmentation, $\mathrm{Ni}$ level recorded in the current study ranged between 2.46 and $0.68 \mathrm{ppm}$ which were lower than those reported by Malik and Zeb (2009) in cattle egret from Ravi river, Pakistan but higher than its concentration in great tits from Belgium (Dauwe et al., 2004).

Mercury emissions from industrial and natural sources have the ability to bioaccumulate in different animals. Mercury level in the current study ranged between 0.51 and $0.89 \mathrm{ppm}$ in IA which is higher than those estimated in Osprey (Hughes et al., 1997) and similar to those estimated in black-crowned night-herons (Golden et al., 2003).

Arsenic, on the other hand, is a serious toxin (Mudhoo et al., 2011), in the current study, cattle egret feather had As level from 0.32 to $0.89 \mathrm{ppm}$ which is lower than those recorded for cattle egret in Pakistan (Abdullah et al., 2015).

It has been suggested that concentration of heavy metals in blood reflect their level in food (Evers et al., 2005), this may explain the higher accumulation of metals in the blood of industrial birds because they have large quantities of food represented by insects and worms available in urban garbage and industrial wastes. In comparison to other studies, the cattle egret blood in the current study showed higher concentration in As, $\mathrm{Cd}, \mathrm{Hg}, \mathrm{Zn}$ and $\mathrm{Cu}$ as compared to blackcrowned night heron from highly contaminated Baltimore harbour, USA (Golden et al., 2003) and higher $\mathrm{Ni}$ and $\mathrm{Pb}$ levels as compared to Ospreys from Chesapeake and Delaware Bays, USA (Rattner et al., 2008).

\section{Haematological Parameters}

Differences in erythrocytes count and packed cell volume in the blood of the cattle egret between the two study area may be due to intoxication with heavy metal especially lead and zinc; $\mathrm{Pb}$, for example, suppresses aminolevulinic acid dehydratase and ferrochelatase which are important for synthesis of haeme causing decreased haemoglobin synthesis and resulting in anaemia, appearance of immature and abnormal red blood cells in the peripheral blood (Pattee et al., 2006; Katavolos et al., 2007).

Red blood cell count and hematocrit changes could be used as a predictor of poisoning with heavy metal in birds (Millaku et al., 2015).Similar to the current study results, Katavolos et al. (2007) found a decreased RBCs count and PCV levels in Canada geese, this could be explained by heavy metals intoxication which is responsible for hemolysis which in turn increase osmotic fragility and anaemia especially $\mathrm{Pb}$ and $\mathrm{Cd}$. Moreover, elevated concentrations of heavy metals caused increased hemolysis and destruction of RBCs (Leggett, 1993).

White blood cells in the current study increased significantly in industrial birds as compared to rural birds. Leukocytosis in birds is usually associated with infectious or non-infectious reasons leading to immune system impairments (Alagbe, 2015), this finding is in agreement with Ogwuegbu and Muhanga (2005) who reported that lead and copper trigger an increase in WBCs count. 


\section{Physiological changes in the cattle Egret, Bubulcus ibis, as a Bioindicator of air pollution in New Damietta City, Egypt}

\section{Biochemical Parameters}

Biochemically, the current study results showed IA birds have a significant increase in the activity of ALT and AST and in the concentration of total protein, albumin, ammonia, uric acid, bilirubin, creatinine, triglycerides and cortisol while cholesterol levels were significantly lower in IA than RA.

In this study, both ALT and AST showed a significant increase in the IA birds compared with RA birds. The increases in ALT and AST above the normal values usually reflecte liver damage (Rao et al., 2006). Therefore, the increments in those enzymes in cattle egret in IA may be an indicator of histopathological damage to the liver, especially liver is the main organ involved in detoxification (Akan et al., 2010). In line with the current results, AST and ALT activities in Japanese quail increased significantly when exposed to $\mathrm{Cd}$ and $\mathrm{Pb}$, meaning severe liver damage (Hamidipour et al., 2016). In contrast, ALT and AST decreased in broiler chicks after exposure to lead and arsenic (Alagbe, 2015).

The current study also concerned with whether total protein or albumin are affected by metals or not. Both total protein and albumin levels were significantly higher in IA birds than RA birds. Increased levels of total protein and albumin could be an indicator for high protein diet (Jenni and Jenni-Eiermann, 1998) rather than metal induced effect. Cattle egret usually feed on different insects such as crickets, flies, moths, grasshopper, spiders and earthworms (Seedikkoya et al., 2007). The main waste dumping yard of new Damietta city is located within IA (the industrial sector of the city), solid and decaying wastes from factories, shops, residences, vegetable markets, hospitals and slaughterhouses are dumped every day. Based on this fact, this waste yard is a rich source for the favoured cattle egret food that is richer in proteins content as compared to the rural area which contains mainly vegetation. Similar results were found also in cattle egret populations collected from different sites in India (Seedikkoya, 2003; Seedikkoya et al., 2005)

In this study, creatinine and uric acid concentrations were significantly higher in IA birds than RA birds. Creatinine level is naturally constant in normal status and its increase in blood is an indicator of kidney dysfunction. Similar results were found in quails (Hamidipour et al., 2016). This increment in creatinine may be caused by the toxic impact of some elements such as $\mathrm{Pb}$ and $\mathrm{Cd}$ on kidney function. Moreover, uric acid increase may indicate nephrotoxicity of some heavy metal especially $\mathrm{Pb}$ and $\mathrm{Cd}$ (Khaki et al., 2011). Elevated uric acid levels may reflect present stress, poor status, or a compensation mechanism (Cohen et al., 2007). In the same line, great tits Parus major showed elevated uric acid levels in the polluted area more than their respective level in less polluted area in Antwerp, Belgium (Geens et al., 2009).

Based on the results of this study, triglyceride concentration was significantly higher in industrial birds than in rural birds. Elevated concentrations of triglyceride usually is indicator of fat absorption (Jenni and Jenni-Eiermann, 1998)which reflects the feeding status of cattle egret and abundance of its food in this study. Similar findings were reported in great tits (Parus major) nestlings where they showed high triglyceride levels in polluted area indicating an abundance of food and high feeding rate (Geens et al., 2009). On contrary, triglyceride level in Japanese quail dropped significantly after exposure to lead indicating malabsorption (Hamidipour et al., 2016).

The increase in cortisol is widely used as a biomarker of heavy metalinduced stress (Franceschini et al., 2009), regarding the current results, IA birds had elevated cortisol levels more than those from RA. These results in agreement with 
Naglaa F. Elarabany and Omnya A. El-Batrawy

another study on birds where cortisol level increased due to metal pollution (Wayland et al., 2003), similarly, increased cortisol concentration was reported in marine iguanas (Amblyrhynchus cristatus) following acute exposure 7 days after an oil spill (Wikelski et al., 2001). In disagreement with our results, Franceschini et al. (2009) reported that the corticosterone level increased as a stress response induced by mercury in free-living tree swallows, Tachycineta bicolour. It appears cortisol behave without predictable patterns with different contaminants.

\section{Oxidative Stress Biomarkers}

The present results show significant changes in oxidative stress biomarkers and some antioxidant defences parameters (MDA, CAT and GPx activities) except SOD in the blood of cattle egret from metal contaminated area (such as industrial sector in New Damietta city). These changes indicate that the birds are affected by oxidative stress in response to heavy metal contamination.

$\mathrm{Cu}$ and $\mathrm{Zn}$ are redox-active metals while $\mathrm{Pb}, \mathrm{Cd}$, $\mathrm{As}$ and $\mathrm{Hg}$ are redoxinactive elements which can produce oxidative stress by interfering with prooxidant/antioxidant balance (Koivula and Eeva, 2010). In general, these elements can produce reactive oxygen species (ROS) and may decrease the major antioxidants of cells (i.e. GPx) and change the levels of MDA, SOD and CAT (Espín et al., 2016).

The significant increase in malondialdehyde level (MDA) in the polluted area (IA) could be used as a useful biomarker for oxidative stress and lipid peroxidation in cattle egret exposed to metal contamination. Similar results were reported in different birds such as white stork, Ciconia ciconia, chicks (Tkachenko and Kurhaluk, 2014) and forester's terns, Sterna forsteri, chicks (Hoffman et al., 2011).
Glutathione peroxidase (GPx) is mainly involved in biotransformation mechanisms, thiol transfer, and free radicals destruction (Rana et al., 2002), so changes in GPx activity could be considered as a valuable biomarker to assess increased oxidative stress induced by metal (Isaksson, 2010).

The current results show that GPx activity decreased significantly in IA birds as compared to RA birds, many heavy metals have the ability to inhibit antioxidant enzymes by interacting with sulfhydryl groups of them. These results are in agreement with Mateo et al. (2003) who found significantly low GPx activity in mallard, Anas platyrhynchos, and Canada goose, Branta Canadensis, after exposure to lead and also in Eurasian eagle owls (Bubo bubo) exposed to different heavy metals (Espín et al., 2014b). In contrast to the current results, GPx activity showed a significant increment in white stork (Tkachenko and Kurhaluk, 2014) and house sparrow, Passer domisticus (Herrera-Duenas et al., 2014).

Birds that live in metal-polluted habitats may have higher oxidative stress or changes in enzyme activity as a result of metal exposure. CAT is a liver enzyme which is related to oxidative stress, in the present study, cattle egret from IA showed a significantly higher catalase activity than those from RA. In the same line, pied flycatcher nestlings exhibited an increase in CAT activity in relation to $\mathrm{Pb}$ contamination in northern Sweden (Berglund et al., 2007) and Griffon vulture (Gyps fulvus) during exposure to $\mathrm{Cd}$ and $\mathrm{Cu}$ in Valencia, Spain (Espín et al., 2014a).On the contrary, house sparrows had a significant decline in CAT activity after 30 days exposure to $\mathrm{Pb}$ (Cid et al., 2018), while exposure to some heavy metal did not alter the CAT activity in Japanese quail (Paskova et al., 2011).

Generally, exposure to heavy metal contaminated area caused oxidative stress in cattle egret. Berglund et al. (2007) also found that pied flycatcher, Ficedula 


\section{Physiological changes in the cattle Egret, Bubulcus ibis, as a Bioindicator of air pollution in New Damietta City, Egypt}

hypoleuca, nestlings in industrial area were affected by oxidative damage. Moreover, Pied Flycatchers exposed to concentrations of arsenic, calcium, cadmium, copper, nickel, lead and zinc showed increased oxidative stress markers near $\mathrm{Cu}-\mathrm{Ni}$ smelters (Berglund et al., 2011).

The current results could be concluded that heavy metals induced deleterious effects on cattle egret. The decreased haematological parameters and changes in biochemical measurements along with increased oxidative damage and decreased antioxidant mechanisms could be used as a useful tool to assess the health condition of the birds and provides positive correlation with different environmental burdens. Cattle egret could be a potential tool for bio-monitoring local heavy metal pollution, but further studies should be conducted for several successive years on bioaccumulation of heavy metals in birds and plants as well to give a realistic picture on current environmental contamination in these areas.

\section{Acknowledgement}

The authors thank the Scientific Research Centre at Damietta University for the financial support of this work. Thanks are to Soul of Prof. G. A. AbdAllah, for revising the project proposal before submission

\section{REFERENCES}

Abd-Allah, G.A.; Mansy, S.E.; Hasab ElNaby, S.E.and El-Arabany, N.F. (2008). Bird Community At 20062007 In New Damiatta, Egypt. Mansoura J. Biol., 36 (2): 77-92.

Abdullah, M.; Fasola, M.; Muhammad, A.; Malik, S.A.; Bostan, N.; Bokhari, H.; Kamran, M.A.; Shafqat, M.N.; Alamdar, A.and Khan, M. (2015). Avian feathers as a non-destructive bio-monitoring tool of trace metals signatures: a case study from severely contaminated areas. Chemosphere, 119: 553-561.

Adout, A.; Hawlena, D.; Maman, R.; PazTal, O.and Karpas, Z. (2007). Determination of trace elements in pigeon and raven feathers by ICPMS. Inter. J.Mass Spectrometry, 267: 109-116.

Agusa, T.; Matsumoto, T.; Ikemoto, T.; Anan, Y.; Kubota, R.; Yasunaga, G.; Kunito, T.; Tanabe, S ;.Ogi, H.and Shibata, Y. (2005). Body distribution of trace elements in black-tailed gulls from Rishiri Island, Japan: age-dependent accumulation and transfer to feathers and eggs. Environ. Toxicol. and Chem., 24: 2107-2120.

Akan, J.; Abdulrahman, F.; Sodipo, O.and Chiroma, Y. (2010). Distribution of heavy metals in the liver, kidney and meat of beef, mutton, caprine and chicken from Kasuwan Shanu market in Maiduguri Metropolis, Borno State, Nigeria. Res. J.Appl. Sci., Engineering and Technol., 2: 743-748.

Alagbe, J.O. (2015). Effect of Heavy Metals Contamination on Performance, Blood Profile of Broiler Chicks Fed Corn-Soya Meal Diet International J. Sci. and Res. (IJSR), 5: 6.

Albayrak, T.and Mor, F. (2011). Comparative tissue distribution of heavy metals in house sparrow (Passer domesticus, Aves) in polluted and reference sites in Turkey. Bull. Environ. Contam. and Toxicol., 87: 457.

Aloupi, M.; Karagianni, A.; Kazantzidis, S.and Akriotis ,T. (2017). Heavy metals in liver and brain of waterfowl from the Evros delta, Greece. Archives of Environ. Contam. and Toxicol., 72: 215-234.

ATSDR (2004). Agency for Toxic Substances and Disease Registry, 
Naglaa F. Elarabany and Omnya A. El-Batrawy

Public Health Statement Copper, CAS\#:7440-50-8, https://www.atsdr.cdc.gov/phs/phs.a sp?id=204\&tid=37.

Awan, M.A.; Ahmed, S.H.; Aslam, M.R.; Qazi, I.A.and Baig, M.A. (2013). Determination of heavy metals in ambient air particulate matter using laser-induced breakdown spectroscopy. Arabian Journal for Science and Engineering, 38: 16551661.

Berglund, A.M.; Koivula, M.and Eeva, T. (2011). Species-and age-related variation in metal exposure and accumulation of two passerine bird species. Environ. Pollut., 159: 23682374.

Berglund, Å.M.; Sturve, J.; Förlin, L.and Nyholm, N. (2007). Oxidative stress in pied flycatcher (Ficedula hypoleuca) nestlings from metal contaminated environments in northern Sweden. Environmental research, 105: 330-339.

Brait, C.H.H. and Antoniosi Filho, N.R. (2011). Use of feathers of feral pigeons (Columba livia) as a technique for metal quantification and environmental monitoring. Environmental monitoring and assessment, 179: 457-467.

Burger, J.and Gochfeld, M. (2000). Metal levels in feathers of 12 species of seabirds from Midway Atoll in the northern Pacific Ocean. Science of the Total Environ., 257: 37-52.

Burger, J.and Gochfeld, M. (2002). Effects of chemicals and pollution on seabirds. CRC Press, Boca Raton, FL, pp. 485-525.

Burger, J.and Gochfeld, M. (20 .(04Metal levels in eggs of common terns (Sterna hirundo) in New Jersey: temporal trends from 1971 to 2002. Environ. Res., 94: 336-343.

Burger, J.and Gochfeld, M. (2009). Mercury and other metals in feathers of common eider (Somateria mollissima) and tufted puffin (Fratercula cirrhata) from the Aleutian chain of Alaska. Archives of Environ. Contam. and Toxicol., 56: 596-606.

Burger, J.; Parsons, K.; Benson, T.; Shukla, T.; Rothstein, D.and Gochfeld, M. (1992). Heavy metal and selenium levels in young cattle egrets from nesting colonies in the northeastern United States, Puerto Rico, and Egypt. Archives of Environ. Contam. and Toxicol., 23: 435-439.

Cheng, K.; Tian, H.; Zhao, D.; Lu, L.; Wang, Y.; Chen, J.; Liu, X.; Jia , W.and Huang, Z. (2014). Atmospheric emission inventory of cadmium from anthropogenic sources. Inter. J. Environ. Sci. and Technol., 11: 605-616.

Cid, F.D.; Fernández, N.C.; Pérez-Chaca, M.V.; Pardo, R.; Caviedes-Vidal, E.and Chediack, J.G. (2018). House sparrow biomarkers as lead pollution bioindicators. Evaluation of dose and exposition length on hematological and oxidative stress parameters. Ecotoxicol. and Environ. Safety, 154: 154-161.

Cohen, A.; Klasing, K.and Ricklefs, R. (2007). Measuring circulating antioxidants in wild birds. Comparative Biochemistry and Physiology Part B: Biochemistry and Molecular Biology, 147: 110121.

Das, R.; Khezri, B.; Srivastava, B.; Datta, S.; Sikdar, P.K.; Webster, R.D.and Wang, X. (2015). Trace element composition of PM2. 5 and PM10 from Kolkata-a heavily polluted Indian metropolis. Atmospheric Pollut. Res., 6: 742-750.

Dauwe, T.; Bervoets, L.; Blust, R.; Pinxten, R.and Eens, M. (2000). Can excrement and feathers of nestling songbirds be used as biomonitors for heavy metal pollution? Archives of Environ. ontamin. and Toxicol., 39: 541-546. 


\section{Physiological changes in the cattle Egret, Bubulcus ibis, as a Bioindicator of air pollution in New Damietta City, Egypt}

Dauwe, T.; Bervoets, L.; Pinxten, R.; Blust, R.and Eens, M. (2003). Variation of heavy metals within and among feathers of birds of prey: effects of molt and external contamination. Environ. Pollut., 124: 429-436.

Dauwe, T.; Janssens, E.; Bervoets, L.; Blust, R.and Eens, M. (2004). Relationships between metal concentrations in great tit nestlings and their environment and food . Environ. Pollut., 131: 373-380.

EEAA (1995). Egyptian Environmental Affairs Agency."Law No. 4, 1994: Promulgating the environmental law and its executive regulation". Egypt.

El-Batrawy, O.A.; M. I., E.-G.and M. A, A. (2017). Environmental study on atmospheric suspended particulate matter and heavy metals in Sandoub, Egypt. Scientific Journal for Damietta Faculty of Science, 7: 65-73.

Espín, S.; Martínez-López, E.; Jiménez, P.; María-Mojica, P.and GarcíaFernández, A.J. (2014a). Effects of heavy metals on biomarkers for oxidative stress in Griffon vulture (Gyps fulvus). Environmental research, 129: 59-68.

Espín, S.; Martínez-López, E.; Jiménez, P.; María-Mojica, P.and GarcíaFernández, A.J. (2016). Interspecific differences in the antioxidant capacity of two Laridae species exposed to metals. Environmental research, 147: 115-124.

Espín, S.; Martínez-López, E.; LeónOrtega, M.; Martínez, J.E.and García-Fernández, A.J. (2014b). Oxidative stress biomarkers in Eurasian eagle owls (Bubo bubo) in three different scenarios of heavy metal exposure. Environmental research, 131: 134-144.

Evers, D.C.; Burgess, N.M.; Champoux, L.; Hoskins, B.; Major, A.; Goodale, W.M.; Taylor, R.J.; Poppenga,
R.and Daigle, T. (2005). Patterns and interpretation of mercury exposure in freshwater avian communities in northeastern North America. Ecotoxicology, 14: 193221.

Franceschini, M.D.; Lane, O.P.; Evers, D.C.; Reed, J.M.; Hoskins, B.and Romero, L.M. (2009). The corticosterone stress response and mercury contamination in freeliving tree swallows, Tachycineta bicolor. Ecotoxicology, 18: 514521.

Geens, A.; Dauwe, T.and Eens, M. (2009). Does anthropogenic metal pollution affect carotenoid colouration, antioxidative capacity and physiological condition of great tits (Parus major)? Comparative Biochemistry and Physiology Part C: Toxicology \& Pharmacology, 150: 155-163.

Golden, N.; Rattner, B.; McGowan, P.; Parsons, K.and Ottinger, M. (2003). Concentrations of metals in feathers and blood of nestling black-crowned night-herons

(Nycticorax nycticorax) in Chesapeake and Delaware Bays. Bulletin of environmental contamination and toxicology, 70: 0385-0393.

Hamidipour, F.; Pourkhabbaz, H.R.; Banaee, M.and Javanmardi, S. (2016). Bioaccumulation of Lead in the Tissues of Japanese Quails and Its Effects on Blood Biochemical Factors. Iranian Journal of Toxicology Vol, 10.

Herrera-Duenas, A.; Pineda, J.; Antonio, M.T.and Aguirre, J.I. (2014). Oxidative stress of house sparrow as bioindicator of urban pollution. Ecological indicators, 4.9-6 :2

Hoffman, D.J.; Eagles-Smith, C.A.; Ackerman, J.T.; Adelsbach, T.L.and Stebbins, K.R. (2011). Oxidative stress response of Forster's terns 
(Sterna forsteri) and Caspian terns (Hydroprogne caspia) to mercury and selenium bioaccumulation in liver, kidney, and brain. Environmental Toxicology and Chemistry, 30: 920-929.

Hughes, K.D.; Ewins, P.J.and Clark, K.E. (1997). A Comparison of Mercury Levels in Feathers and Eggs of Osprey (Pandion haliaetus) in the North American Great Lakes. Archives of environmental contamination and toxicology, 33: 441-452.

Hutton, M.and Goodman, G. (1980). Metal contamination of feral pigeons Columba livia from the London area: Part 1-tissue accumulation of lead, cadmium and zinc. Environmental Pollution Series A, Ecological and Biological, 22: 207-217.

Isaksson, C. (2010). Pollution and its impact on wild animals: a metaanalysis on oxidative stress. EcoHealth, 7: 342-350.

Jenni, L.and Jenni-Eiermann, S. (1998). Fuel supply and metabolic constraints in migrating birds. Journal of Avian Biology, 29: 521528.

Johnston, R.F.and Janiga, M. (1995). Feral pigeons. Oxford University Press on Demand.

Katavolos, P.; Staempfli, S.; Sears, W.; Gancz, A.; Smith, D.and Bienzle, D. (2007). The effect of lead poisoning on hematologic and biochemical values in trumpeter swans and Canada geese. Veterinary clinical pathology, 36: 341-347.

Kaur, N.and Dhanju, C. (2013). Heavy metals concentration in excreta of free living wild birds as indicator of environmental contamination. Bioscan, 8: 108.1093-9

Kekkonen, J.; Hanski, I.K.; Väisänen, R.A.and Brommer, J.E. (2012). Levels of heavy metals in House Sparrows (Passer domesticus) from urban and rural habitats of southern Finland. Ornis Fennica, 89: 91.

Khaki, Z.; Amoli, J.; Lesan, V.and Esfahani ,T. (2011). Changes of serum biochemistry in short term toxicity with lindane pesticide in broiler chickens. Journal of Veterinary Research, 66: 1-81.

Kim, J.and Koo, T.-H. (2007). The use of feathers to monitor heavy metal contamination in herons, Korea . Archives of environmental contamination and toxicology, 53: 435-441.

Kim, J.and Koo, T.-H. (2008). Heavy metal concentrations in feathers of Korean shorebirds. Archives of environmental contamination and toxicology, 55: 122-128.

Koivula, M.J.and Eeva, T .(2010) .Metalrelated oxidative stress in birds. Environmental Pollution, 158: 2359-2370.

Koivula, M.J.; Kanerva, M.; Salminen, J.P.; Nikinmaa, M.and Eeva, T. (2011). Metal pollution indirectly increases oxidative stress in great tit (Parus major) nestlings. Environmental research, 111: 362370.

Leggett, R.W. (1993). An age-specific kinetic model of lead metabolism in humans. Environmental health perspectives, 101: 598-616.

Leonzio, C.; Bianchi, N.; Gustin, M.; Sorace, A.and Ancora, S. (2009). Mercury ,lead and copper in feathers and excreta of small passerine species in relation to foraging guilds and age of feathers. Bulletin of environmental contamination and toxicology, 83: 693.

Lodge, J.and James, P. (1988). Methods of air sampling and analysis. CRC Press.

Lumeij, J. (1997). Avian clinical biochemistry. Clinical Biochemistry of Domestic Animals (Fifth Edition). Elsevier, pp. 857-883. 


\section{Physiological changes in the cattle Egret, Bubulcus ibis, as a Bioindicator of air pollution in New Damietta City, Egypt}

Malik, R.N.and Zeb, N. (2009). Assessment of environmental contamination using feathers of Bubulcus ibis L., as a biomonitor of heavy metal pollution, Pakistan. Ecotoxicology, 18: 522-536.

Martínez-Gómez, C.; Vethaak, A.; Hylland, K.; Burgeot, T.; Köhler, A.; Lyons, B.; Thain, J.; Gubbins, M.and Davies, I. (2010). A guide to toxicity assessment and monitoring effects at lower levels of biological organization following marine oil spills in European waters. ICES Journal of Marine Science, 67: 1105-1118.

Mateo, R.; Beyer, W.N.; Spann, J.W.and Hoffman, D.J. (2003). Relation of fatty acid composition in leadexposed mallards to fat mobilization, lipid peroxidation and alkaline phosphatase activity. Comparative Biochemistry and Physiology Part C: Toxicology \& Pharmacology, 135: 451-458.

Millaku, L.; Imeri, R.; Orllati, J.and Trebicka, A. (2015). The Impact of Lead and Nickel environmental pollution on blood levels of liver enzymes in House Sparrow (Passer domesticus) in Kosovo. Animal and Veterinary Sciences, 3: 28-31.

Mudhoo, A.; Sharma, S.K.; Garg, V.K.and Tseng, C.-H. (2011). Arsenic: an overview of applications, health ,and environmental concerns and removal processes. Critical Reviews in Environmental Science and Technology, 41: 435-519.

NAAQS (1994). National Ambient Air Quality Standards, European Commission, CPCB, Delhi, India.

NAAQS (2009). Revised National Ambient Air Quality Standards, European Commission, CPCB, Delhi, India.

Nam, D.-H.; Anan, Y.; Ikemoto, T.; Okabe, Y.; Kim, E.-Y.;
Subramanian, A.; Saeki, K.and Tanabe, S. (2005). Specific accumulation of 20 trace elements in great cormorants Phalacrocorax carbo (from Japan. Environmental Pollution, 134: 503-514.

Ogwuegbu, M.and Muhanga, W. (2005). Investigation of lead concentration in the blood of people in the copper belt province of Zambia. J Environ, 1: 66-75.

Pal, R.; Gupta, A.and Tripathi, A. (2014). Assessment of heavy metals in suspended particulate matter in Moradabad, India. Journal of environmental biology, 35: 357.

Pappas, A.C.; Karadas, F.; Surai, P.F.; Wood, N.A.; Cassey, P.; Bortolotti, G.R.and Speake, B.K. (2006). Interspecies variation in yolk selenium concentrations among eggs of free-living birds: the effect of phylogeny. Journal of Trace Elements in Medicine and Biology, 20: 155-160.

Paskova, V.; Paskerova, H.; Pikula, J.; Bandouchova, H.; Sedlackova, J.and Hilscherova, K. (2011). Combined exposure of Japanese quails to cyanotoxins, Newcastle virus and lead: Oxidative stress responses. Ecotoxicology and environmental safety, 74: 2082-2090.

Pattee, O.H.; Carpenter, J.W.; Fritts, S.H.; Rattner, B.A.; Wiemeyer, S.N.; Royle, J.A.and Smith, M.R .(2006) . Lead poisoning in captive Andean condors (Vultur gryphus). Journal of wildlife diseases, 42: 772-779.

Rana, S.; Allen, T.and Singh, R. (2002). Inevitable glutathione, then and now

Rao, Y.V.; Das, B.; Jyotyrmayee, P.and Chakrabarti, R. (2006). Effect of Achyranthes aspera on the immunity and survival of Labeo rohita infected with Aeromonas hydrophila. Fish \& Shellfish Immunology, 20: 263-273. 
Naglaa F. Elarabany and Omnya A. El-Batrawy

Rattner, B.A.; Golden, N.H.; Toschik, P.C.; McGowan, P.C.and Custer, T.W. (2008). Concentrations of Metals in Blood and Feathers of Nestling Ospreys (Pandion haliaetus) in Chesapeake and Delaware Bays. Archives of environmental contamination and toxicology, 54: 114-122.

Salam, A.; Hossain, T.; Siddique, M.and Alam, A.S. (2008). Characteristics of atmospheric trace gases, particulate matter, and heavy metal pollution in Dhaka, Bangladesh. Air Quality, Atmosphere \& Health, 1: 101.

Scheifler, R.; Coeurdassier, M.; Morilhat, C.; Bernard, N.; Faivre, B.; Flicoteaux, P.; Giraudoux, P.; Noël, M.; Piotte, P.and Rieffel, D. (2006). Lead concentrations in feathers and blood of common blackbirds (Turdus merula) and in earthworms inhabiting unpolluted and moderately polluted urban areas. Science of the Total Environment, 371: 197-205.

Seedikkoya, K. (2003). Comparative ecology of certain paddy field birds with emphasis on the habitat quality. Unpublished $\mathrm{PhD}$ Thesis, University of Calicut, India: 66-103.

Seedikkoya, K.; Azeez, P.and Shukkur, E. (2005). Cattle Egret Bubulcus ibis habitat use and association with cattle. Forktail, 21: 174.

Seedikkoya, K.; Azeez, P.and Shukkur, E.A. (2007). Cattle Egret as a biocontrol agent. Zoos' Print Journal, 22: 2864-2866.

Sonne, C.; Bustnes, J.O.; Herzke, D.; Jaspers, V.L.; Covaci, A.; Halley, D.J.; Moum, T.; Eulaers, I.; Eens, M.and Ims, R.A. (2010). Relationships between organohalogen contaminants and blood plasma clinical-chemical parameters in chicks of three raptor species from Northern Norway.
Ecotoxicol. and Environ. Safety, 73: 7-17.

Swaileh, K.and Sansur, R. (2006). Monitoring urban heavy metal pollution using the House Sparrow (Passer domesticus). Journal of Environmental Monitoring, 8: 209213.

Thongcharoen, K.; Robson, M.G.and Keithmaleesatti, S. (2018). Determination of heavy metals in eggs of Little Grebe (Tachybaptus ruficollis) around the wastewater treatment ponds, Khon Kaen University. Human and Ecological Risk Assessment: An Inter. J., 24: 362-376.

Tkachenko, H.and Kurhaluk, N. (2014). Blood oxidative stress and antioxidant defense profile of White Stork Ciconia ciconia chicks reflect the degree of environmental pollution. Ecolog. Questions, 18:79-89.

Wayland, M.; Smits, J.J.; Gilchrist, H.G.; Marchant, T.and Keating, J. (2003). Biomarker responses in nesting, common eiders in the Canadian arctic in relation to tissue cadmium, mercury and selenium concentrations. Ecotoxicol., 12: 225-237.

Wikelski, M.; Romero, L.M.and Snell, H.L. (2001). Marine iguanas oiled in the Galapagos. Science, 292: 437-438.

Zakey, A.; Abdel-Wahab, M.; Pettersson, J.C ;.Gatari, M.and Hallquist, M. (2008). Seasonal and spatial variation of atmospheric particulate matter in a developing megacity, the Greater Cairo, Egypt. Atmósfera, 21: 171-189.

Zhang, Y.; Ruan, L.; Fasola, M.; Boncompagni, E.; Dong, Y.; Dai, N.; Gandini ,C.; Orvini, E.and Ruiz, X. (2006). Little egrets (Egretta garzetta) and trace - metal contamination in wetlands of China. Environmental Monitoring and Assessment, 118: 355-368. 
Physiological changes in the cattle Egret, Bubulcus ibis, as a Bioindicator of air pollution in New Damietta City, Egypt

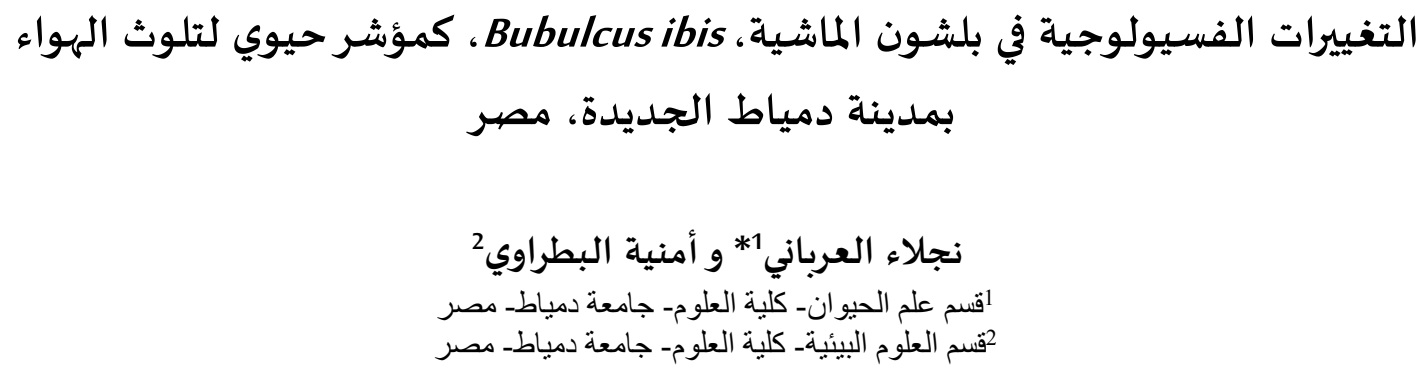

المستخلص

تتراكم المعادن الثقيلة المختلفة فى البيئة نتيجة للأنشطة البشرية المكثفة، والتي تؤثر سلبا على الحياة البرية. تطور الكائنات الحية

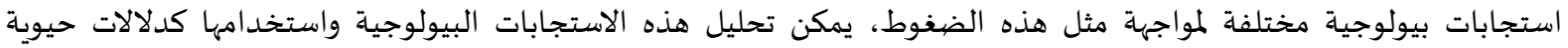

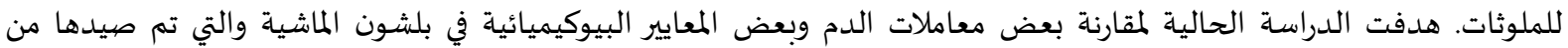

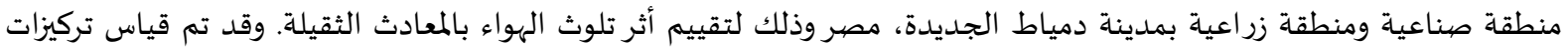

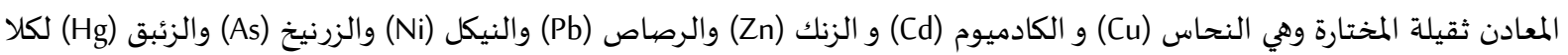

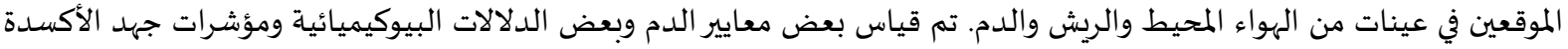

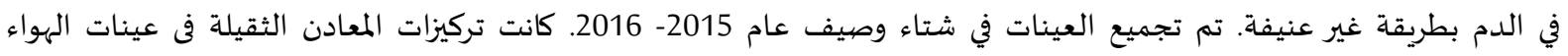

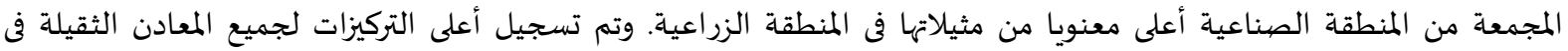

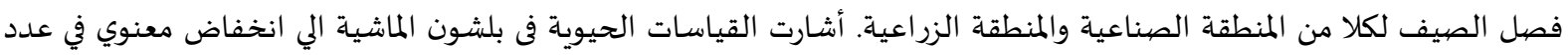

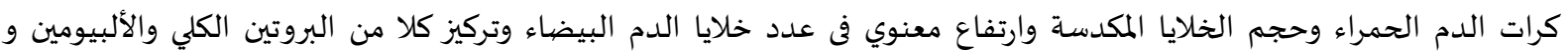

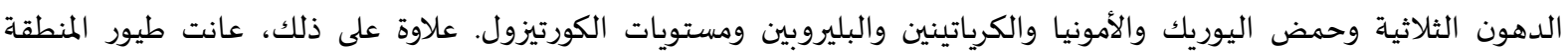

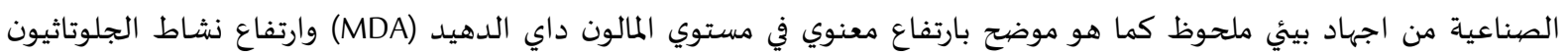

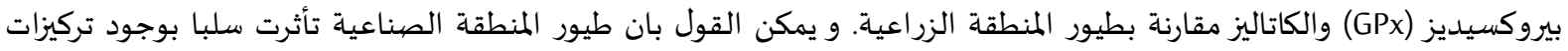

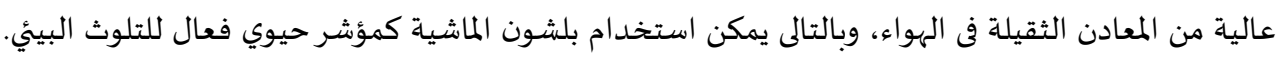

